\title{
A Study of the Roles of Leadership Styles and Attitudes with Social Responsibility for the 4th Industrial Revolution
}

\author{
SangWoo Hahm ${ }^{1}$ \\ College of Business Administration, Soongsil University, \\ Seoul, 06978 - Korea. \\ [e-mail: bload@ssu.ac.kr] \\ *Corresponding author: SangWoo Hahm
}

Received Septebmer 5, 2019; revised December 17, 2019; accepted January 2, 2019; published February 29, 2020

\begin{abstract}
The $4^{\text {th }}$ Industrial Revolution (FIR) has already begun. Corporations have to fulfill their social responsibilities to the FIR. This study explores the leadership and attitudes required in the FIR era for companies to fulfill their social responsibilities. In the FIR era, workers should have certain attitudes, such as self-efficacy, expectancy, and acceptance of change. If workers have these attitudes, they will be able to make a difference in the future. This study suggests the leadership styles that are needed to improve these attitudes. Participation, creativity, delegation of leadership, and inspirational motivation of leaders involves organizational change and improvement of organizational performance. This paper demonstrates the kind of leadership that is more important for each attitude through statistical analysis. Furthermore, when workers have these attitudes, not only the future, but also their current performance can be improved. To explain this relationship, the paper describes the effect of attitudes on job satisfaction. If workers have certain attitudes, their current and future performance will improve. As a result of the research, all four leadership styles had positive effects on attitudes toward FIR, and attitudes showed a mediating effect on the relationship between leadership styles and job satisfaction. In addition, it has been proven that the role of participative and delegating leadership, which is more memberoriented leadership, is more important. Leadership will enable workers to have a particular attitude through member-centered leadership, and workers will be able to increase current and future performance. Through these efforts, companies will be able to increase their performance in the current and FIR era, and fulfill their social responsibilities more faithfully. Therefore, in the FIR era, companies will play an important role in the development of society, and create new values.
\end{abstract}

Keywords: self-efficacy, expectancy, acceptance of change, leadership, job satisfaction

A preliminary version of this paper was presented at APIC-IST 2019, and was selected as an outstanding paper. 


\section{Introduction}

Companies have to adapt to new changes, and strive for social development. In particular, corporate social responsibility (CSR) is a very important factor contributing to the improvement of long-term performance of the enterprise, and the development of society. In today's rapidly changing environment, the importance of ethical management is increasing day-by-day, in order to maintain and grow the company. While currently, the company is pursuing only short-term profit or focusing on visible financial performance, among the various tasks that focus on sustainable management and long-term development of the enterprise, ethical management is an essential element that is becoming increasingly important. The fourth industrial revolution (FIR) is underway in our lives. This study explores the relevance of attitudes and leadership needed in the FIR era to companies that practice social enterprise, social responsibility, and ethical management. In the FIR era, if companies donot make use of Internet information, they will be culled. New information will be produced quickly and in large quantities based on the Internet and mobile. New leadership is very important for companies to adapt to FIR. Today's leadership involves organizational change. Leaders are the key to organizational change. Thus, leaders need to harness Internet information, fulfill social responsibilities and drive new changes in their organizations. In the FIR era, if leaders do not change their organizations, interpret sufficient information, make decisions, and fail to fulfill their social responsibilities, companies will not adapt to the new era. With new changes, companies and workers need to adapt to change and technology, and establish new strategies and attitudes to the future [1,2]. With regard to FIR, workers need to have certain attitudes, and by having these attitudes, they will be able to generate higher performance in the near future. In particular, important attitudes in relation to the transition to the fourth industrial age are self-efficacy, expectation, and the acceptance of change [2]. These attitudes will ensure future performance. In order to adapt to future society and new changes, and to improve performance, companies need to pursue shared values of organization, and adapt to new technologies $[3,4]$. For this purpose, it is also necessary to pursue better leadership for future or specific organizations, such as the FIR [5]. Hence, this study explains the particular leadership styles needed to improve these attitudes for future performance. These specific leadership styles that are being studied in business administration today will improve critical attitudes, such as self-efficacy, expectation, and the acceptance of change for FIR. Typically, creative leadership, which encourages members' creative potential and capacity [6], member-focused leadership that supports the growth of members [7], or utilizes inspirational motivation [8,9], and leader's intelligence [10] will influence members' motivation to accept the change. In addition, this study explains the role of self-efficacy in change, as well as the influence of leadership [11]. These leaderships will exert influence, so that members have certain attitudes. In addition, this paper explains the effects on the current performance, as well as the future, when workers have these attitudes through specific leaderships. Job satisfaction is a representative indicator of the performance of current members in organizational research. In general, job satisfaction directly affects the performance of workers [12]. By enhancing the self-efficacy, expectation, and acceptance of change in the fourth industrial age of a member through specific leadership, workers will be satisfied with the present job and the future, and create high performance. This study tries to explain what leadership is needed for the future FIR. These specific leaderships will have positive attitudes toward the future, and will effect current and future performance improvements. Furthermore, improving the satisfaction and performance of the members will improve the competitiveness of the organization, and lead to the creation of new value 
of the organization. Hence, companies should create new value in the near future like the present and the FIR, and contribute to social development with social responsibility.

\section{Literature Review}

\subsection{Job satisfaction}

Job satisfaction is one of the most active and continuously studied subjects in organizational research, because it is one of the most representative variables for measuring individual and organizational performance. Job satisfaction refers to perception and cognition of the degree to which an employee likes their own job or are satisfied with their job environment. The degree of satisfaction with work is the psychological condition of the individual themselves, while the job environment includes factors such as pay and fringe benefits, job security, and relationships with supervisors $[13,14]$. Although job satisfaction has been studied extensively in relation to organizational performance, this concept needs to be more clearly distinguished, because there are similar concepts, such as morale [12]. For example, job satisfaction is related to the worker's individual situation, but morale concentrates on how workers relate to a shared purpose within an organization. Also, morale emphasizes individual feelings about the future, whereas job satisfaction more appropriately focuses on present and past situations [15]. Job satisfaction is a feeling and positive emotional state of workers arising from their work and work experience [12]. Job satisfaction involves the feelings of individual achievement, and the facilitation and promotion of the job value of workers [16]. Hence, it can be said that job satisfaction means workers' comprehensive satisfaction with the job itself, the job experience, and job environment. Also, the performance of members with high job satisfaction can be improved. Workers' satisfaction with their jobs has a direct impact on a company's overall performance. Workers with higher job satisfaction are more likely to be productive, more flexible, and handle pressure, but are less likely to think of leaving their organization. Therefore, job satisfaction directly reflects the current performance of employees and organization.

\subsection{Attitudes for FIR}

\subsubsection{Self-efficacy for FIR}

The expectations for the future can be divided into efficacy and outcome expectancy. Efficacy is related to the point of view of the self [17]. Self-efficacy means individual belief in one's capabilities, and ability to achieve a specific level of result and performance. This personal belief produces various effects on perspective, emotional, behavioral, and motivational processes. Also it can be defined as "beliefs in one's capabilities to mobilize the motivation, cognitive resources, and courses of action needed to meet given situational demands” [19: p.408]. Self-efficacy does not give value to workers themselves. Since selfefficacy is a belief about the ability that workers themselves are confident they can perform their work successfully, this is closely related to successful work and performance improvement [20]. Workers with a high level of self-efficacy have a tendency to make more effort and accept challenges when faced with difficult problems [21]. In contrast, the performance of workers with low self-efficacy may also be low. Thus, self-efficacy is an important factor explaining differences in motivation, learning, and task performance among individuals as a significant attitude toward individual performance [22, 23]. Self-efficacy is a belief that performance can be achieved in a given situation, and it improves motivation [24]. 
Therefore, self-efficacy for FIR is an individual's belief that it is more motivated to change into the FIR era, and that it will be able to achieve high results in this age. If individuals have high self-efficacy for FIR, they will have more confidence in the change to FIR, and will be able to achieve higher performance in the FIR era [2]. In addition, when workers believe that they can accomplish work on their own, they can be more satisfied with their job [14, 21]. If workers themselves believe that they can perform certain tasks, they can predict the outcome of the work, and achieve a high level of performance. Through this process, job satisfaction is increased [14, 21]. Therefore, self-efficacy can be a predictor of job satisfaction, and hypothesis 1 was set as follows.

\section{H1. Self-efficacy for FIR will have a positive relationship with job satisfaction.}

\subsubsection{Expectancy for FIR}

People generally have a subjective ability to anticipate the future. Forecasts for the future affect current behavior. People prepare for, or anticipate, what will happen in the future [17]. This can be expected to be the subjective probability of an individual having to do things about the future [25]. Expectancy for the future affects current motivation, job behavior, and performance. Positive expectations can lead to more positive current behavior [26]. Hence, expectancy is a motivational factor that measures performance, and it is a predictor of current behavior through perspective on the future [27]. Expectancy for FIR involves a positive attitude toward this future, as well as a belief that it will change to the FIR age in the near future [2]. Therefore, expectancy for FIR means that the individual has a more positive attitude toward the FIR age, and predicts the future positively. Those who have positive expectations about the future will be able to adapt more easily, and achieve higher results in the coming future. In particular, because expectancy has a direct impact on workers' motivation, workers with positive expectancy for the future are more motivated, and more satisfied with their job [26, 27]. Therefore, hypothesis 2 was set as follows.

\section{H2. Expectancy for FIR will have a positive relationship with job satisfaction.}

\subsubsection{Acceptancy of change for FIR}

Acceptance of change means the willingness to adopt it more aggressively, and adapt to change without rejecting the new change. Today's corporate environment is changing rapidly. The transition from the present to the FIR is also proceeding rapidly. The adaptation of a company to the environment not only means changing the system and technology, but also means that the workers change together. Organizations that are struggling with adaptation to new changes fall behind, and fail [28]. However, not everyone and every organization can easily adapt to the new environment. People and companies are afraid of change, or they are interested in the benefits that can be gained by maintaining existing ones. Compared to those who reject change, those who accept change can become more effective and successful in a new environment [29, 30]. Therefore, acceptance of change for FIR implies workers' willingness to accommodate and adapt to changes in the FIR age. Workers with higher acceptance of change for FIR will adapt more effectively, and create higher performance in this age. The performance of workers who adapt to changes well is generally high. Leaders can also motivate members by engaging them in change [28, 32]. It is rare to directly examine the relationship between job satisfaction and acceptance of change. However, current performance, such as job satisfaction, can be improved for workers who accept change. Hypothesis 3 is as follows: 
H3. Acceptancy of change for FIR will have a positive relationship with job satisfaction.

\subsection{Leadership styles and attitudes for FIR}

\subsubsection{Participative leadership and attidudes for FIR}

Participative leadership refers to leadership in which leaders give members the opportunity to participate in decision making, and that members have influence on making decisions or business operation [31, 32]. Participative leadership is a field of empowering leadership, and is used as a very similar concept. Empowerment is the sharing of power. Participation leadership is the sharing of decision-making power with members [33, 34]. Participative leadership can improve work performance by encouraging members to work on their own. Also, since decision making is a choice for future business operations, the influence of participative leadership will affect the attitudes of members to the future, such as the FIR age. Firstly, participative leadership provides guidance on how leaders work and participate in their work as a model for their members. Thus, the members become aware of how to improve their performance [7], and their self-efficacy increases [35]. By participating and being empowered, members increase their confidence, and improve their feelings of selfefficacy [36]. Therefore, participative leadership plays a role in increasing self-efficacy for the FIR era. Second, participative leadership allows members to participate in decision making, to expand new knowledge, and learn skills [33]. Participative leaders have a more change-oriented attitude, as members make new opportunities [37]. Therefore, this leadership has a positive effect on members' acceptance of change, such as transfer to the FIR era. Third, by empowering leadership to involve members in decision-making, they become more independent, and participate in goal-setting processes themselves [38]. Generally, a goal is a plan for the future that leaders present to their members [32]. When members become independent and participate in goals, they will be able to have a more positive attitude in the future. Therefore, participative leadership will improve the expectancy of the members. Based on this theoretical relevance, the following hypotheses were set:

H4 . Participative leadership will increase positive attitudes for FIR.

H4-1. Participative leadership will increase self-efficacy for FIR.

H4-2. Participative leadership will increase expectancy for FIR.

H4-3. Participative leadership will increase acceptance of change for FIR.

\subsubsection{Creative leadership and attitudes for FIR}

Creative leadership usually encourages the organizational members' creative potential and capacity [6]. This means that the creative leader does not need to be creative themself, but the leader should influence the followers' creativity. The creative member focuses on developing members' human capital, such as their personal capabilities, abilities, knowledge, information, task skills, and employee job experience. Moreover, the creative leader emphasizes the importance of social capital, such as the network of human relationships in the organization. In addition, the creative leader is oriented to task risk, making a decision in an uncertain environment, and unconventional actions [6]. Creative leadership plays a critical role in creating a company environment that creates new knowledge and promotes inventions [6, 39]. Thus, this leadership can encourage a creative environment, and also influence members' attitudes and performance. First, creative leadership influences members' self-concepts, such as self-worth, by allowing them to work with creative ideas [40]. The 
specific support of the leader gives the members confidence in their work [33]. Thus, creative leadership promotes the creativity of the members, and the members will have more self-efficacy in their work, while demonstrating their creativity. Second, the specific support of the leader influences the expectancy of the members [33, 41]. Creative leadership helps members to pursue new values, take risks, and accept challenges $[6,40]$. Through this leadership, members will have the belief that they will be able to achieve creative results in the future. This belief is directly related to the expectations of the members [17, 25]. Creative leadership involves a long-term perspective not only for immediate performance, but also for future creative performance [6, 42]. Therefore, creative leadership will affect the expectancy of the members for the future, such as the FIR era. Third, creative leaders are sensitive to new knowledge and change, because they take risks in the external environment, and seek new opportunities. This leadership stimulates the members to be creative [6]. Also, the leader's creative leadership style makes the members have originality and innovation [40]. Leaders become role models, and influence members [32, 39]. Innovation and new value pursuits all involve change, so that creative leadership can better accommodate risk and new things for the future. Therefore, creative leaders will improve members' acceptance of change for the FIR. With this relationship, the following hypotheses were set:

H5 . Creative leadership will increase positive attitudes for the FIR.

H5-1. Creative leadership will increase self-efficacy for the FIR.

H5-2. Creative leadership will increase expectancy for the FIR.

H5-3. Creative leadership will increase acceptance of change for the FIR.

\subsubsection{Inspirational motivation and attidudes for the FIR}

While traditional leadership is characterized by transactional leadership, which involves situational reward and management by exception, transformational leadership influences its members through inspirational motivation, individualized consideration, idealized influence, and intellectual stimulation. In particular, inspirational motivation is a feature of a leader that allows a leader to present a new vision, creativity, and a more positive outlook to the future for its members. Also, inspirational motivation is the leader's capacity to present a clear vision of the future, explain challenging standards to members, and endure controversial problems $[8,9]$. If the leader presents a clear vision to the members, and shows optimism about the future with him, the members will also have a more positive view of the future and change. Hence, when the leader provides inspirational motivation to the members, their attitudes can be changed. First, a transformational leader influences members' self-efficacy. This leader becomes a role model for the followers, persuades them to achieve a goal, and affects the psychological arousal of members [43]. In particular, inspirational motivation can give leaders confidence in achieving a goal, so that members can have confidence in achievement, and have a sense of self-efficacy [32, 44]. Therefore, inspirational motivation will improve the self-efficacy of the FIR, by giving the members the confidence that they will be able to achieve the future direction, such as the FIR. Similar to the mechanism by which the inspirational motivation of the transformational leader influences self-efficacy, it also improves the expectancy of the members $[43,45]$. Because inspirational motivation gives a clear vision of the future and believes that it can be achieved, workers have confidence and expectations about the future with leaders. In particular, clear blueprints presented through inspirational motivation can be clearly perceived by members of the future with the leader $[9,38,46]$. Therefore, inspirational motivation will influence the members to have more positive expectations in the future, such as the FIR. Particular leadership styles, 
such as transformational leadership, lead to changes in organizations and members [32, 39]. The inspirational motivation of the leader suggests the members' new values that are different from the existing ones, and stimulates them to follow them [46]. Thus, members are more receptive to new changes. Leaders are also accompanied by changes to the FIR era. Therefore, by inspirational motivation, if leaders give their followers the vision they need for FIR, and they believe that they can achieve it, they will better accommodate change. In this regard, the following hypotheses were set.

H6 . Inspirational motivation will increase positive attitudes for the FIR.

H6-1. Inspirational motivation will increase self-efficacy for the FIR.

H6-2. Inspirational motivation will increase expectancy for the FIR.

H6-3. Inspirational motivation will increase acceptance of change for the FIR.

\subsubsection{Delegating leadership and attidudes for the FIR}

Delegation is a type of decision-making [47]. Delegation refers to lowering within the hierarchy the supportive and directive behavior of a leader. Delegating leadership is the optimal style, to give decision-making power to members, not leaders [48]. When a leader delegates the decision-making and working methods without directing the members, they perform their own tasks, and the performance of workers with ability and willingness can be improved [49]. Delegation positively affects job satisfaction, work capacity, and performance [47]. First, since delegating leadership gives autonomy to members and delegates tasks and decisions, members become more immersed and spontaneous in their work. Thus, members who have spontaneity can become more confident about their work $[49,50]$. Therefore, delegating leadership gives confidence in the capacity of the workers, and they will have a higher self-efficacy for the present and the future. Second, autonomy improves intrinsic motivation, and positively impacts new value creation [49-51]. Workers with an orientation to create new value have a positive expectancy for the future, as well as the principle that creative leadership enhances members' expectancy [6, 17, 25, 40], Since workers create new value for themselves, they expect a better outcome. The follower who trusts the leader will be intrinsically motivated, and expects to achieve high performance. The expectancy of this result will have a positive impact on the expectations for the FIR. Third, intrinsic motivation from autonomy also helps people to adapt to new business [51]. Intrinsically motivated people are less afraid of change, because they tend to challenge new work [49-51]. Therefore, these people will be better able to adapt to new changes, such as the FIR. Based on these relationships, the following hypotheses were set.

H7 . Delegating leadership will increase positive attitudes for the FIR.

H7-1. Delegating leadership will increase self-efficacy for the FIR.

H7-2. Delegating leadership will increase expectancy for the FIR.

H7-3. Delegating leadership will increase acceptance of change for the FIR.

\section{Research Framework}

The independent variables in this study are leadership styles. Leadership styles involve participative leadership, creative leadership, inspirational motivation, and delegating leadership. Leadership styles will have a positive effect on job satisfaction, which is the dependent variable. In these relationships, positive attitudes toward FIR will have mediating effects. The mediating variables in this study are self-efficacy for FIR, expectancy for FIR, 
and acceptance of change for FIR. The relevance of these variables is shown in Fig. 1.

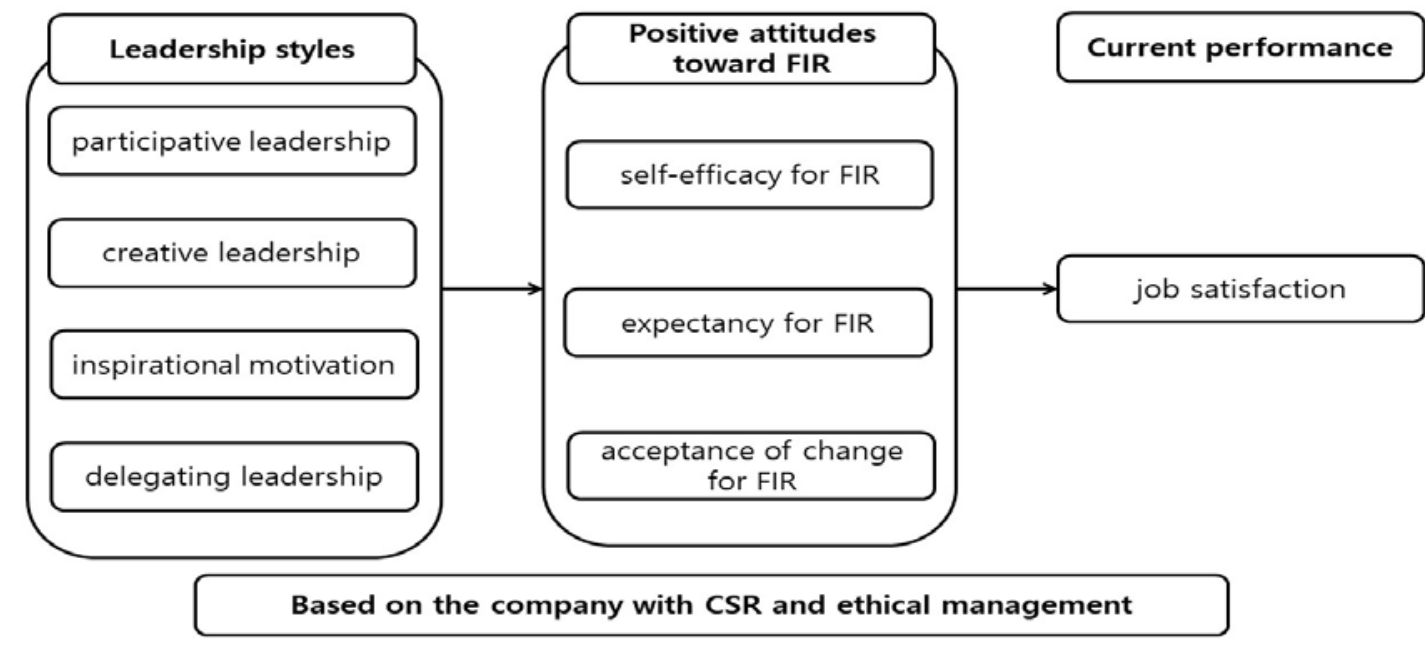

Fig. 1. Research Model

\section{Participants and Measurement}

\subsection{Participants}

Data was collected from 191 workers who were members of social enterprises or companies with social responsibility. Traditionally, one variable or one factor should have at least 10-15 samples [52, 53]. For regression analysis, statistically significant results can be obtained when the sample size is at least 20. The sample size has to be at least 50 to be effective if there are more than two variables in multiple regression analysis [54, 55]. This study used multiple regression analysis, so it should have at least 50 samples. In addition, there are eight variables in this study, so a minimum of 120 samples or more ensures that the results of statistical analysis are valid. Thus, the 191 samples used in this study are large enough to describe the population.

In general, companies need to exercise social responsibility. The reason why a company should have social responsibility is that first, a company is a member of society itself. From the external environment of society, companies receive resources. All enterprise systems are open to the external environment, such as market, labor force, technologies, and the like. Therefore, management activities cannot be carried out while ignoring society, which is the environment of gear. Second, CSR provides firms with an opportunity for competitive advantage. Since the image of a company fulfilling its social responsibilities is improved, customers' brand loyalty can be enhanced. In addition, governments and social organizations can offer various benefits and friendly policies to companies with social responsibility. Therefore, CSRhas a positive impact on both social and business development [56, 57].

In terms of gender, there were 140 males (73.3 \%) and 51 females (26.7 \%). In terms of age, 34 were in their twenties (17.8 \%), 64 in their thirties (33.5\%), 65 in their forties (34\%), and 28 were older than fifty (14.7\%). In terms of academic background, 10 had completed high school (5.2\%), 149 had bachelor degrees (78 \%), and 32 had master degrees or doctorates $(16.8 \%)$. In regards to their length of employment, 14 had worked for less than 1 year (7.3 \%), 62 had worked 1-5 years (32.5 \%), 59 had worked 5-10 years (30.9\%), and 56 
had worked longer than 10 years (29.3\%). In regards to their length of working with the current leader, 32 had worked for less than 1 year (16.8\%), 106 had worked 1-5 years (55.5\%), 25 had worked 5-10 years (13.1\%), and 28 had worked longer than 10 years (14.7\%).

\subsection{Measurement}

All items were measured on a Likert 7-point scale. First, participative leadership was measured by 6 items, including, "My leader encourages work group members to express ideas/suggestions", and "My leader makes decisions that are based only on his/her own ideas" [37]. Second, creative leadership was measured by 3 items, including, "My leader encourages risk taking and unconventional actions", "My leader focuses on developing human capital (the individual capabilities, knowledge, skills and experience of a firm's employees)" [6]. Third, Inspirational motivation was measured by 4 items, including, "My leader articulates a compelling vision of the future", "My leader talks enthusiastically about what needs to be accomplished" [8]. Fourth, delegating leadership was measured by 4 items, including, "My leader gives me a lot of autonomy in my work", "My leader gives me a lot of delegation" [49, 50]. Fifth, job satisfaction was measured by 3 items, including, "All in all, I am satisfied with my job”, "In general, I don't like my job” [13]. Sixth, self-efficacy for FIR was measured by 5 items, including, "I feel certain I can perform my job well in the FIR era", "I will have confidence in my ability to solve problems in the FIR era" [2, 21, 35]. Seventh, expectancy for FIR was measured by 11 items, including, "I will get more compensation and bonus in the FIR era", "I will have ability, skill and development opportunity in the FIR era" $[2,25,26]$. Eighth, acceptance of change for the FIR was measured by 6 items, including, "I have become more enthusiastic since moving to the FIR era", "I see the FIR as a challenge and an opportunity for the most part, rather than hanging on to notions of the past" $[2,28$, 29].

\section{Analysis}

For the statistical analysis, this study utilizes confirmatory factor analysis (CFA), reliability, descriptive statistics, and correlation and regression analysis [58-60]. First of all, Table 1 suggests CFA. Four leadership styles (independent variables), three attitudes for FIR (mediate variables), and job satisfaction (depedent variable) have proven validity in this research.

Table 1. Results of confirmatory factor analysis.

\begin{tabular}{|c|c|c|c|c|c|}
\hline \multirow{4}{*}{$\begin{array}{l}\text { absolute fit } \\
\text { index }\end{array}$} & $X^{2}(\mathrm{p})$ & $1,372.562$ & & AVE & C.R \\
\hline & $\overline{X^{2} / \mathrm{df}}$ & 1.735 & expectancy for the FIR & 2.641 & .930 \\
\hline & RMR & .073 & participative leadership & .634 & .875 \\
\hline & RMSEA & .062 & creative leadership & .622 & .774 \\
\hline \multirow{3}{*}{$\begin{array}{l}\text { incremental fit } \\
\text { index }\end{array}$} & TLI & .908 & self-efficacy for the FIR & .714 & .909 \\
\hline & CFI & .916 & delegating leadership & .729 & .874 \\
\hline & IFI & .917 & job satisfaction & .721 & .807 \\
\hline \multirow{2}{*}{$\begin{array}{l}\text { parsimonious fit } \\
\text { index }\end{array}$} & PNFI & .756 & acceptance of change for the & .612 & .877 \\
\hline & PGFI & .657 & inspirational motivation & .698 & .850 \\
\hline
\end{tabular}


Table 2 shows the results of reliability (Cronbach's alpha) and descriptive statistics (mean and standard deviation). All variables have adequate level of Cronbach's alpha (above .8).

Table 2. Reliability and descriptive statistics.

\begin{tabular}{|c|c|c|c|}
\hline & Cronbach's alpha & Mean & Std. deviation \\
\hline \hline job satisfaction & .881 & 4.717 & 1.222 \\
\hline self-efficacy for FIR & .926 & 4.976 & .989 \\
\hline expectancy for FIR & .950 & 4.768 & .991 \\
acceptance of change for FIR & .899 & 4.896 & .927 \\
\hline participative leadership & .909 & 4.774 & 1.001 \\
\hline creative leadership & .832 & 4.721 & 1.042 \\
\hline inspirational motivation & .901 & 4.649 & 1.125 \\
\hline delegating leadership & .915 & 4.732 & 1.118 \\
\hline
\end{tabular}

Table 3 indicates the results of correlation among all variables. Each variable has a positive relationship with other variables in significance level. In particular, job satisfaction was positively related to self-efficacy for the FIR (.347), supporting hypothesis 1 , expectancy for FIR (.375), supporting hypothesis 2, and acceptancy of change for the FIR (.395), supporting hypothesis 3.

Table 3. Results of correlation.

\begin{tabular}{|c|c|c|c|c|c|c|c|c|}
\hline & 1 & 2 & 3 & 4 & 5 & 6 & 7 & 8 \\
\hline \hline 1 & - & & & & & & & \\
2 & $.347^{* * *}$ & - & & & & & & \\
\hline 3 & $.375^{* * *}$ & $.812^{* * *}$ & - & & & & & \\
\hline 4 & $.395^{* * *}$ & $.785^{* * *}$ & $.779^{* * *}$ & - & & & & \\
\hline 5 & $.478^{* * *}$ & $.438^{* * *}$ & $.510^{* * *}$ & $.524^{* * *}$ & - & & & \\
\hline 6 & $.533^{* * *}$ & $.347^{* * *}$ & $.457^{* * *}$ & $.457^{* * *}$ & $.785^{* * *}$ & - & & \\
\hline 7 & $.566^{* * *}$ & $.353^{* * *}$ & $.467^{* * *}$ & $.402^{* * *}$ & $.785^{* * *}$ & $.790^{* * *}$ & - & \\
\hline 8 & $.520^{* * *}$ & $.494^{* * *}$ & $.510^{* * *}$ & $.522^{* * *}$ & $.746^{* * *}$ & $.678^{* * *}$ & $.641^{* * *}$ & - \\
\hline$p$
\end{tabular}

1: job satisfaction, 2: self-efficacy for the FIR, 3: expectancy for the FIR, 4 :acceptance of change for the FIR, 5: participative leadership, 6: creative leadership, 7: inspirational motivation, 8: delegating leadership.

Table 4 presents the result of the linear regression, which explains the effect of participative leadership on job satisfaction and the mediating effects of attitudes for the FIR (self-efficacy for the FIR, expectancy for the FIR, and acceptance of change for the FIR). As a result, in the relationship between participative leadership and job satisfaction, self-efficacy for the FIR $(\beta=.171$, sig=.016), expectancy for the FIR $(\beta=.178$, sig=.016), and acceptance of change for the FIR $(\beta=.199$, sig=.008) proved to have significant mediating effects. Also, the 
$\mathrm{R}^{2}$ value, which means the model explanatory power, is increased compared to step 1 (.228). In addition, the results of the SOBEL test showed that all the results of the mediating effects were significant. Therefore, hypothesis 4 , which includes 4-1, 4-2, and 4-3, is supported.

Table 4. The effect of participative leadership.

\begin{tabular}{|c|c|c|c|c|c|c|c|c|c|c|c|c|}
\hline \multicolumn{13}{|c|}{ dependent : job satisfaction } \\
\hline & \multicolumn{3}{|c|}{ step 1} & \multicolumn{3}{|c|}{$\begin{array}{l}\text { mediate: self- } \\
\text { efficacy for FIR }\end{array}$} & \multicolumn{3}{|c|}{$\begin{array}{c}\text { mediate: } \\
\text { expectancy for } \\
\text { FIR }\end{array}$} & \multicolumn{3}{|c|}{$\begin{array}{c}\text { mediate: } \\
\text { acceptance of } \\
\text { change for FIR }\end{array}$} \\
\hline & $\beta$ & $t$ & sig & $\beta$ & $t$ & sig & $\beta$ & $t$ & sig & $\beta$ & $t$ & sig \\
\hline participativ & .47 & 7.47 & .00 & .40 & 5.74 & .00 & .38 & 5.27 & .00 & .37 & 5.05 & .00 \\
\hline e & 8 & 6 & 0 & 3 & 3 & 0 & 7 & 7 & 0 & 4 & 9 & 0 \\
\hline mediate & \multicolumn{3}{|c|}{-} & .17 & 2.43 & .01 & .17 & 2.42 & .01 & .19 & 2.69 & .00 \\
\hline$R^{2}$ & \multicolumn{3}{|c|}{.228} & \multicolumn{3}{|c|}{.252} & \multicolumn{3}{|c|}{.252} & \multicolumn{3}{|c|}{.257} \\
\hline$\Delta R^{2}$ & \multicolumn{3}{|c|}{-} & \multicolumn{3}{|c|}{.024} & \multicolumn{3}{|c|}{.024} & \multicolumn{3}{|c|}{.029} \\
\hline$F$ & \multicolumn{3}{|c|}{$55.894^{* * *}$} & \multicolumn{3}{|c|}{$31.637^{* * *}$} & \multicolumn{3}{|c|}{$31.623^{* * *}$} & \multicolumn{3}{|c|}{$32.491^{* * *}$} \\
\hline SOBEL & \multicolumn{3}{|c|}{-} & \multicolumn{3}{|c|}{$2.279^{*}$} & \multicolumn{3}{|c|}{$2.341^{*}$} & \multicolumn{3}{|c|}{$2.575^{* *}$} \\
\hline
\end{tabular}

Table 5 displays the effect of creative leadership on job satisfaction and the mediating effects of three attitudes. As a result, in the relationship between creative leadership and job satisfaction, self-efficacy for the FIR $(\beta=.185$, sig=.005), expectancy for the FIR $(\beta=.167$, sig=.015), and acceptance of change for the FIR $(\beta=.191$, sig=.005) proved to have significant mediating effects. In addition, the $\mathrm{R}^{2}$ value is increased compared to step 1 (.284), and the SOBEL test proved that all the results of the mediating effects were significant. Therefore, hypothesis 5 (5-1, 5-2, and 5-3) is also supported.

Table 5. The effect of creative leadership.

\begin{tabular}{|c|c|c|c|c|c|c|c|c|c|c|c|c|}
\hline \multicolumn{13}{|c|}{ dependent : job satisfaction } \\
\hline & \multicolumn{3}{|c|}{ step 1} & \multicolumn{3}{|c|}{$\begin{array}{l}\text { mediate: self- } \\
\text { efficacy for FIR }\end{array}$} & \multicolumn{3}{|c|}{$\begin{array}{c}\text { mediate: } \\
\text { expectancy for } \\
\text { FIR }\end{array}$} & \multicolumn{3}{|c|}{$\begin{array}{c}\text { mediate: } \\
\text { acceptance of } \\
\text { change for FIR }\end{array}$} \\
\hline & $\beta$ & $t$ & sig & $\beta$ & $t$ & sig & $\beta$ & $t$ & sig & $\beta$ & $t$ & sig \\
\hline creative & .53 & 8.65 & .00 & .46 & 7.27 & .00 & .45 & 6.68 & .00 & .44 & 6.55 & .00 \\
\hline leadershi & 3 & 1 & 0 & 9 & 4 & 0 & 6 & 1 & 0 & 5 & 1 & 0 \\
\hline mediate & \multicolumn{3}{|c|}{ - } & .18 & 2.86 & .00 & .16 & 2.44 & .01 & .19 & 2.81 & .00 \\
\hline$R^{2}$ & \multicolumn{3}{|c|}{.284} & \multicolumn{3}{|c|}{.314} & \multicolumn{3}{|c|}{.306} & \multicolumn{3}{|c|}{.313} \\
\hline$\Delta R^{2}$ & \multicolumn{3}{|c|}{-} & \multicolumn{3}{|c|}{.030} & \multicolumn{3}{|c|}{.022} & \multicolumn{3}{|c|}{.029} \\
\hline$F$ & \multicolumn{3}{|c|}{$74.836^{* * *}$} & \multicolumn{3}{|c|}{$42.965^{* * *}$} & \multicolumn{3}{|c|}{$41.389^{* * *}$} & \multicolumn{3}{|c|}{$42.744^{* * *}$} \\
\hline SOBEL & \multicolumn{3}{|c|}{-} & \multicolumn{3}{|c|}{$2.483^{*}$} & \multicolumn{3}{|c|}{$2.314^{*}$} & \multicolumn{3}{|c|}{$2.600^{* *}$} \\
\hline
\end{tabular}

Table 6 shows the effect of inspirational motivation of a leader on job satisfaction and the mediating effects of attitudes. According to the result, all attitudes for the FIR have a mediating effect between inspirational motivation and job satisfaction (self-efficacy for the 
FIR: $\beta=.168$, sig=.008, expectancy for the FIR: $\beta=.142$, sig=.036, and acceptance of change for the FIR: $\beta=.199$, sig=.002) Moreover, the $\mathrm{R}^{2}$ value is increased compared to step $1(.321)$, and all mediating effects were demonstrated by the SOBEL test. Hence, hypothesis 6 (6-1, 62 , and 6-3) is accepted.

Table 6. The effect of inspirational motivation.

\begin{tabular}{|c|c|c|c|c|c|c|c|c|c|c|c|c|}
\hline \multicolumn{13}{|c|}{ dependent : job satisfaction } \\
\hline & \multicolumn{3}{|c|}{ step 1} & \multicolumn{3}{|c|}{$\begin{array}{l}\text { mediate: self- } \\
\text { efficacy for FIR }\end{array}$} & \multicolumn{3}{|c|}{$\begin{array}{l}\text { mediate: } \\
\text { expectancy for } \\
\text { FIR }\end{array}$} & \multicolumn{3}{|c|}{$\begin{array}{c}\text { mediate: } \\
\text { acceptance of } \\
\text { change for FIR }\end{array}$} \\
\hline & $\beta$ & $t$ & sig & $\beta$ & $t$ & sig & $\beta$ & $t$ & sig & $\beta$ & $t$ & sig \\
\hline \multirow{2}{*}{$\begin{array}{c}\text { inspiration } \\
\text { al }\end{array}$} & .56 & 9.44 & .00 & .50 & 8.03 & .00 & .50 & 7.44 & .00 & .48 & 7.59 & .00 \\
\hline & 6 & 2 & n & 7 & $\Delta$ & n & $n$ & 1 & $n$ & 6 & 1 & n \\
\hline mediate & \multicolumn{3}{|c|}{ - } & .16 & 2.66 & .00 & .14 & 2.11 & .03 & .19 & 3.10 & .00 \\
\hline$R^{2}$ & \multicolumn{3}{|c|}{.321} & \multicolumn{3}{|c|}{.345} & \multicolumn{3}{|c|}{.336} & \multicolumn{3}{|c|}{.354} \\
\hline$\Delta R^{2}$ & \multicolumn{3}{|c|}{-} & \multicolumn{3}{|c|}{.024} & \multicolumn{3}{|c|}{.015} & \multicolumn{3}{|c|}{.033} \\
\hline$F$ & \multicolumn{3}{|c|}{$89.173^{* * *}$} & \multicolumn{3}{|c|}{$49.582^{* * *}$} & \multicolumn{3}{|c|}{$47.640^{* * *}$} & \multicolumn{3}{|c|}{$54.455^{* * *}$} \\
\hline SOBEL & \multicolumn{3}{|c|}{-} & \multicolumn{3}{|c|}{$2.371^{*}$} & \multicolumn{3}{|c|}{$2.024^{*}$} & \multicolumn{3}{|c|}{$2.771^{* *}$} \\
\hline
\end{tabular}

Table 7 indicates the effect of delegating leadership on job satisfaction and the mediating effects of attitudes. Statistical analysis showed that the mediating effect of all attitudes was confirmed. However, the mediating effect of self-efficacy for FIR was relatively low $(\beta$ $=.120$, sig=.094). The expectancy for the FIR $(\beta=.149$, sig=.038) and acceptance of change for the FIR $(\beta=.170$, sig=.019) are proven to have sufficient mediating effects. Further, the $\mathrm{R}^{2}$ value is increased compared to step $1(.270)$, and the SOBEL test results supported all mediating effects. Hence, hypothesis 7 (7-1, 7-2, and 7-3) is accepted.

Table 7. The effect of delegating leadership.

\begin{tabular}{|c|c|c|c|c|c|c|c|c|c|c|c|c|}
\hline \multicolumn{13}{|c|}{ dependent : job satisfaction } \\
\hline & \multicolumn{3}{|c|}{ step 1} & \multicolumn{3}{|c|}{$\begin{array}{l}\text { mediate: self- } \\
\text { efficacy for FIR }\end{array}$} & \multicolumn{3}{|c|}{$\begin{array}{l}\text { mediate: } \\
\text { expectancy for } \\
\text { FIR }\end{array}$} & \multicolumn{3}{|c|}{$\begin{array}{c}\text { mediate: } \\
\text { acceptance of } \\
\text { change for FIR }\end{array}$} \\
\hline & $\beta$ & $t$ & sig & $\beta$ & $t$ & sig & $\beta$ & $t$ & sig & $\beta$ & $t$ & sig \\
\hline delegating & .52 & 8.36 & .00 & .46 & 6.47 & .00 & .44 & 6.19 & .00 & .43 & 5.99 & .00 \\
\hline leadership & 0 & 4 & 0 & 1 & 6 & 0 & 4 & 7 & 0 & 1 & 2 & 0 \\
\hline mediate & \multicolumn{3}{|c|}{ - } & .12 & 1.68 & .09 & .14 & 2.08 & .03 & .17 & 2.35 & .01 \\
\hline$R^{2}$ & \multicolumn{3}{|c|}{.270} & \multicolumn{3}{|c|}{.281} & \multicolumn{3}{|c|}{.287} & \multicolumn{3}{|c|}{.291} \\
\hline$\Delta R^{2}$ & \multicolumn{3}{|c|}{-} & \multicolumn{3}{|c|}{.011} & \multicolumn{3}{|c|}{.016} & \multicolumn{3}{|c|}{.021} \\
\hline$F$ & \multicolumn{3}{|c|}{$69.950^{* * *}$} & \multicolumn{3}{|c|}{$36.732^{* * *}$} & \multicolumn{3}{|c|}{$37.767^{* * *}$} & \multicolumn{3}{|c|}{$38.593^{* * *}$} \\
\hline SOBELTES & \multicolumn{3}{|c|}{-} & \multicolumn{3}{|c|}{1.644} & \multicolumn{3}{|c|}{$2.206^{*}$} & \multicolumn{3}{|c|}{$2.272^{*}$} \\
\hline
\end{tabular}


In addition, this article conducted an analysis comparing the impact of each leadership style on attitudes to the FIR. Table 8 shows that each leadership style has more or less influence on self-efficacy for the FIR, expectancy for the FIR, and acceptance of change for the FIR. First, delegating leadership ( $\beta=.395$, sig=.000) has the most influence on self-efficacy for the FIR, and participative leadership $(\beta=.207$, sig $=.098)$ has a significant effect on self-efficacy for the FIR. Second, only delegating leadership $(\beta=.271$, sig=.005) affects expectancy for the FIR. Finally, delegating leadership $(\beta=.287$, sig $=.002)$ has the strongest influence on acceptance of change for the FIR, followed by participative leadership $(\beta=.319$, sig=.008).

This result implies that delegating leadership and participative leadership are particularly important to improve attitudes for the FIR. Inspirational motivation is the leader's behavior and a part of transformational leadership, which is leader-centered leadership [8, 9]. Creative leadership is the trait or behavior of a leader that increases the creativity of the members [6]. In contrast, delegating leadership and participative leadership are more member-oriented leadership styles [33, 36, 37, 47, 50]. In particular, delegating leadership is more a membercentered leadership than participative leadership. Thus, in order for followers to have attitudes for the FIR, the leader will need to exercise influence with more member-oriented leadership.

Table 8. The effects of leadership styles on attitudes for the FIR.

\begin{tabular}{|c|c|c|c|c|c|c|c|c|c|}
\hline \multirow[t]{3}{*}{ independent } & \multicolumn{9}{|c|}{ dependent } \\
\hline & \multicolumn{3}{|c|}{$\begin{array}{l}\text { self-efficacy } \\
\text { for the FIR }\end{array}$} & \multicolumn{3}{|c|}{$\begin{array}{l}\text { expectancy } \\
\text { for the FIR }\end{array}$} & \multicolumn{3}{|c|}{$\begin{array}{l}\text { acceptance of change } \\
\text { for the FIR }\end{array}$} \\
\hline & $\beta$ & $t$ & sig & $\beta$ & $t$ & sig & $\beta$ & $t$ & sig \\
\hline $\begin{array}{l}\text { participative } \\
\text { leadership }\end{array}$ & .207 & 1.662 & .098 & .190 & 1.574 & .117 & .319 & 2.670 & .008 \\
\hline $\begin{array}{l}\text { creative } \\
\text { leadership }\end{array}$ & -.092 & -.792 & .429 & .026 & .234 & .815 & .098 & .879 & .380 \\
\hline $\begin{array}{l}\text { inspirational } \\
\text { motivation }\end{array}$ & .010 & .089 & .929 & .123 & 1.108 & .269 & -.110 & 1.002 & .318 \\
\hline $\begin{array}{l}\text { delegating } \\
\text { leadership }\end{array}$ & .395 & 4.055 & .000 & .271 & 2.875 & .005 & .287 & 3.075 & .002 \\
\hline$R^{2}$ & \multicolumn{3}{|c|}{.258} & \multicolumn{3}{|c|}{.304} & \multicolumn{3}{|c|}{.318} \\
\hline$F$ & \multicolumn{3}{|c|}{$16.1340^{* * *}$} & \multicolumn{3}{|c|}{$20.3560^{* * *}$} & \multicolumn{3}{|c|}{$21.6670^{* *}$} \\
\hline
\end{tabular}

\section{Conclusion}

\subsection{Results and Implications}

Companies need to fulfill their social responsibilities. The FIR era is approaching our society. The social responsibility of companies will still be important in the FIR era. This study explores the impact of workers' attitudes on their current performance in companies fulfilling their social responsibilities. To further improve these attitudes, it suggests the specific types of leadership that are needed for social enterprises. 
First, attitudes for the FIR, such as self-efficacy for the FIR, expectancy for the FIR, and acceptance of change for the FIR, influence job satisfaction, which is current performance. This result means that certain attitudes toward the future increase current performance. These specific attitudes are needed for workers preparing for the FIR era. These workers will be able to create various opportunities in the near future, called the FIR era. These attitudes are also important for the current performance of workers. According to expectancy theory [25, 26], positive expectancy about the future affects current attitudes, behavior, and outcomes $[24,36]$. If employees have positive attitudes toward the future, not only the future, but also the present performance can be enhanced. Hence, this study asserts the importance of specific attitudes toward the FIR for both the future and the present.

Second, this study suggests the importance of leadership styles as a way to improve these specific attitudes. The mediating effects of attitudes for the FIR have been demonstrated in the relationship between all leadership styles and job satisfaction. These results, of course, explain the importance of attitudes for the FIR, but also involve the positive relationship between current job satisfaction ad all leadership styles, such as participative leadership, creative leadership, inspirational motivation, and delegating leadership.

Thus, the leadership styles suggested in this study all claim to have an effect on improving the current performance of the worker.

Third, all four leadership types have positive impacts on attitudes for FIR. The most important finding in this study is that delegating leadership and participative leadership are more crucial for these attitudes. These leadership types are member-oriented. Rather than having leaders command and control their followers, members can have more positive attitudes toward the future when leaders support, engage, and delegate. These findings underscore the importance of member-centered leadership focused on members in future societies. When leaders engage with and delegate to their members, they will have positive attitudes toward the future, and will achieve higher performance, both now and in the future. Thus, this study argues that leadership, like delegation and participation, is needed for social enterprises.

As a result, leaders can use specific leadership styles to encourage workers to have particular attitudes. Workers with these attitudes will achieve high performance in the present, and create new values in the future. This will improve both the employee and company performance. Furthermore, companies will be able to create new values, gain competitive advantage, and contribute to the development of society with social responsibility in the FIR era.

\subsection{Limitations and Potential Areas of Future Study}

The limitations of this study and suggestions for future research are as follows.

First, this study suggests the attitudes necessary for the FIR era. Time series analysis or longitudinal studies need to be performed on whether workers who have and maintain these attitudes have actually achieved high performance in the future. If the importance of these attitudes is proven, it will be possible to know what variables are also needed for the new changes after the FIR era.

Second, the results of the study emphasize the importance of member-oriented leadership. Thus, more diverse studies should be conducted on more member-oreinted leadership, such as servant leadership [7]. Through these efforts, workers will be able to achieve higher performance in the FIR era. In addition, this study examined the impact of leadership styles and attitudes on job satisfaction, so further study should address whether they affect other 
indicators of current performance, such as organizational commitment, work engagement, and organizational citizenship behavior.

Third, in this research, the influence of leadership styles did not directly target the attitudes for FIR when explaining the theoretical relevance. This study is based on previous studies, which explained leadership styles' influence on general attitudes, such as selfefficacy, expectancy, and acceptance of change. Then it predicted that the leadership styles presented would have an impact on attitudes for the FIR. Although leadership is closely related to the FIR, such as creative leadership, it is necessary to take a deeper look at why these leadership styles affect attitudes for the FIR, rather than general attitudes.

Finally, it is necessary to carry out studies that take into consideration the characteristics of the social enterprise, which is the subject of this study. For example, a more important attitude or leadership may be different between social enterprises and other companies. Also, even if a company fulfills its social responsibilities, workers will not be aware of the company's efforts if the company does not provide workers with information about it. Thus, companies and leaders should try to motivate and provide information about their social responsibilities, so that members can take pride in their organization, and hold it in high esteem.

\section{References}

[1] Mihyun Chung and Jaehyun Kim, "The internet information and technology research directions based on the fourth industrial revolution," KSII Transactions on Internet and Information Systems, vol. 10, no. 3, pp. 1311-1320, March, 2016. Article (CrossRef Link).

[2] Sangwoo Hahm, "Attitudes and performance of workers preparing for the fourth industrial revolution," KSII Transactions on Internet and Information Systems, vol. 12, no. 8, pp. 40384056, August, 2018. Article (CrossRef Link).

[3] Imran Ghani and Mannir Bello, "Agile adoption in IT organizations," KSII Transactions on Internet and Information Systems, vol. 9, no. 8, pp. 3231-3248, August, 2015.

Article (CrossRef Link).

[4] Inkuk Song and Junchul Chun, "Evolving Internet information \& technology as enablers for creating shared values," KSII Transactions on Internet and Information Systems, vol. 9, no. 1, pp. 309-317, January, 2015. Article (CrossRef Link).

[5] Sangwoo Hahm, "Roles of authentic leadership, psychological empowerment and intrinsic motivation on workers' creativity in e-business," Journal of Internet Computing and Services, vol. 19, no. 1, pp. 113-122, February, 2018. Article (CrossRef Link).

[6] Marianna Makri and Terri A. Scandura, "Exploring the effects of creative CEO leadership on innovation in high-technology firms," The Leadership Quarterly, vol. 21, no. 1, pp. 75-88, February, 2010. Article (CrossRef Link).

[7] Robert K. Greenleaf, Servant Leadership: A Journey into the Nature of Legitimate Power and Greatness, Paulist Press, New York, 2002.

[8] Bernard M. Bass and Bruce J. Avolio, The Multifactor Leadership Questionnaire, Mind Garden, Inc., California Republic, 1995.

[9] John E Barbuto Jr, "Motivation and transactional, charismatic, and transformational leadership: A test of antecedents," Journal of Leadership and Organizational Studies, vol. 11, no. 4, pp. 26-40, June, 2005. Article (CrossRef Link).

[10] Chisum Wong and Kenneth S Law, "The effects of leader and follower emotional intelligence on performance and attitude: An exploratory study,” The Leadership Quarterly, vol. 13, no. 3, pp. 243-274, June, 2002. Article (CrossRef Link).

[11] Roland Bénabou and Jean Tirole, "Self-confidence and personal motivation," The Quarterly Journal of Economics, vol. 117, no. 3, pp. 871-915, August, 2002. Article (CrossRef Link). 
[12] Edwin A. Locke, “The Nature and Causes of Job Satisfaction,” in Marvin D. Dunnette (Ed.), “Handbook of Industrial and Organizational Psychology,” RandMc Natlly, Chicago, 1976.

[13] Stanley E. Seashore, Edward E. Lawler, Philip Mirvis and Cortlandt Cammann, Observing and Measuring Organizational Change: A Guide to Field Practice, Wiley, New York, 1982.

[14] Robert P. Quinn and Thomas W. Mangione, "Evaluation weighted model of measuring job satisfaction: A cinderella story,” Organizational Behavior and Human Performance, vol. 10, no. 1, pp. 1-23, August, 1973. Article (CrossRef Link).

[15] Scott Macdonal and Peter Maclntyre, "The generic job satisfaction scale: Scale development and its correlates,” Employee Assistance Quarterly, vol. 13, no. 2, pp. 1-16, 1997. Article (CrossRef Link).

[16] Richard W. Batty and Craig E. Schneier, Personnel Administation: An Experiential Skill Building Approach, Addison-Wesley Publishing Co., Massachusetts, 1981.

[17] Albert Bandura, Social Learning Theory, Englewood Cliffs, Prentice-Hall, New Jersey, 1977.

[18] Albert Bandura, "Self-efficacy,” in Vilayanur S. Ramachaudran (Ed.), "Encyclopedia of Human Behavior,” vol. 4, pp. 71-81, Academic Press, New York, 1994.

[19] Robert Wood and Albert Bandura, "Impact of conceptions of ability on self-regulatory mechanisms and complex decision making,” Journal of Personality and Social Psychology, vol. 56, no. 3, pp. 407-415, March, 1989. Article (CrossRef Link).

[20] Gilad Chen, Stanley M. Gully and Dov Eden, "General self-efficacy and self-esteem: Toward theoretical and empirical distinction between correlated self-evaluations," Journal of Organizational Behavior, vol. 25, no. 3, pp. 375-395, March, 2004. Article (CrossRef Link).

[21] Robert W. Renn and Donald B. Fedor, "Development and field test of a feedback seeking, selfefficacy, and goal setting model of work performance,” Journal of Management, vol. 27, no. 5, pp. 563-583, October, 2001. Article (CrossRef Link).

[22] Gilad Chen, Stanley M. Gully, Jon-Andrew Whiteman and Robert N. Kilcullen, "Examination of relationships among trait-like individual differences, state-like individual differences, and learning performance,” Journal of Applied Psychology, vol. 85, no. 6, pp. 835-847, December, 2000. Article (CrossRef Link).

[23] Timothy A. Judge, "The dispositional causes of job satisfaction: A core evaluations approach," Research in Organizational Behavior, vol.19, pp. 151-188, January, 1997.

[24] Albert Bandura, "Self-efficacy: Toward a unifying theory of behavioral change," Psychological Review, vol. 84, no. 2, pp. 191-215, April, 1977. Article (CrossRef Link).

[25] James M. Olson, Neal J. Roese and Mark P. Zanna, "Expectancies,” in Tory E. Higgins and Arie W. Kruglanski (Ed.), “Social Psychology: Handbook of Basic Principles,” pp. 211-238, Guilford Press, New York, 1996.

[26] Edward E. Lawler III and J.Lloyd Suttle, "Expectancy theory and job behavior," Organizational Behavior and Human Performance, vol. 9, no. 3, pp. 482-503, June, 1973. Article (CrossRef Link).

[27] Allan Wigfield and Jacquelynne S. Eccles, "Expectancy-value theory of achievement motivation," Contemporary Educational Psychology, vol. 25, no. 1, pp. 68-81, February, 2000. Article (CrossRef Link).

[28] Marie H. Kavanagh and Neal M. Ashkanasy, "The impact of leadership and change management strategy on organizational culture and individual acceptance of change during a merger,” British Journal of Management, vol. 17, no. S1, pp. S81-S103, March, 2006. Article (CrossRef Link).

[29] Marylene Gagne, Richard Koestner and Miron Zuckerman, "Facilitating acceptance of organizational change: The importance of self determination," Journal of Applied Social Psychology, vol. 30, no. 9, pp. 1843-1852, September, 2000. Article (CrossRef Link).

[30] Abraham Sagie and Meni Ed Koslowsky, "International Replication Note Decision type, organisational control, and acceptance of change: An integrative approach to participative decision making,” Applied Psychology: An International Review, vol. 45, no. 1, pp. 85-92, January, 1996. Article (CrossRef Link).

[31] Paul L. Koopman and Andre F. Wierdsma, "Participative Management," in Charles De Wolff, Pieter Johan Diederik Drenth and Henk Thierry (Eds.), "Handbook of Work and Organizational 
Psychology(Volume 3): Personnel Psychology,” vol. 3, pp. 297-324, Psychology Press, United Kingdom, 1998.

[32] Gary A. Yukl, Leadership in Organizations(7nd Edition), Prentice Hall, New Jersey, 2010.

[33] Abhishek Srivastava, Kathryn M. Bartol and Edwin A. Locke, "Empowering leadership in management teams: Effects on knowledge sharing, efficacy, and performance," Academy of Management Journal, vol. 49, no. 6, pp. 1239-1251, December, 2006. Article (CrossRef Link).

[34] Edwin A. Locke and David Michael Schweiger, "Participation in Decision Making: One More Look,” in Barry M. Staw (Ed.), "Research in Organizational Behavior,” vol. 1, pp. 265-339, JAI Press, Greenwich, 1979.

[35] Albert Bandura, Self-efficacy: The Exercise of Control, Macmillan, New York, 1997.

[36] Josh A. Arnold, Sharon Arad, Jonathan A. Rhoades and Fritz Drasgow, "The empowering leadership questionnaire: The construction and validation of a new scale for measuring leader behaviors,” Journal of Organizational Behavior, vol. 21, no. 3, pp. 249-269, April, 2000. Article (CrossRef Link).

[37] Mesut Sagnak, "Participative leadership and change-oriented organizational citizenship: The mediating effect of intrinsic motivation," Eurasian Journal of Educational Research, vol. 16, no. 62, pp. 181-194, February, 2016. Article (CrossRef Link).

[38] Craig L. Pearce and Henry P. Sims Jr, "Vertical versus shared leadership as predictors of the effectiveness of change management teams: An examination of aversive, directive, transactional, transformational, and empowering leader behaviors," Group Dynamics: Theory, Research, and Practice, vol. 6, no. 2, pp. 172-197, June, 2002. Article (CrossRef Link).

[49] Richard L. Daft, The Leadership Experience, South-western Publishing Co., Cincinnati, Ohio, 2002.

[40] Michael D Mumford and Jill M Strange, "Leading creative people: Orchestrating expertise and relationships,” The Leadership Quarterly, vol. 13, no. 6, pp. 705-750, December, 2002. Article (CrossRef Link).

[41] Delbert M. Nebeker and Terence R. Mitchell, "Leader behavior: An expectancy theory approach,” Organizational Behavior and Human Performance, vol. 11, no. 3, pp. 355-367, June, 1974. Article (CrossRef Link).

[42] Louise Stoll and Julie Temperley, “Creative leadership: A challenge of our times," School Leadership and Management, vol. 29, no. 1, pp. 65-78, February, 2009. Article (CrossRef Link).

[43] Rajnandini Pillai and Ethlyn A. Williams, "Transformational leadership, self-efficacy, group cohesiveness, commitment, and performance,” Journal of Organizational Change Management, vol. 17, no. 2, pp. 144-159, April, 2004. Article (CrossRef Link).

[44] Shelley A. Kirkpatrick and Edwin A. Locke, "Direct and indirect effects of three core charismatic leadership components on performance and attitudes,” Journal of Applied Psychology, vol. 81, no. 1, pp. 36-51, February, 1996. Article (CrossRef Link).

[45] Dov Eden, "Leadership and expectations: Pygmalion effects and other self-fulfilling prophecies in organizations” The Leadership Quarterly, vol. 3, no. 4, pp. 271-305, Winter, 1992.

Article (CrossRef Link).

[46] Bernard M. Bass and Ronald E. Riggio, Transformational Leadership(2nd Edition), Psychology press, New York, 2006.

[47] Carrie R. Leana, "Predictors and consequences of delegation,” Academy of Management Journal, vol. 29, no. 4, pp. 754-774, December, 1986. Article (CrossRef Link).

[48] Paul Hersey, Kenneth H. Blanchard and Dewey E. Johnson, Management of Organizational Behavior (Vol. 9), Prentice hall, Upper Saddle River, New Jersey, 2007.

[49] Paul Hersey, Kenneth H. Blanchard and Walter E. Natemeyer, "Situational leadership, perception, and the impact of power,” Group and Organization Studies, vol. 4, no. 4, pp. 418-428, December, 1979. Article (CrossRef Link).

[50] Chester A. Schriesheim, Linda L. Neider and Terri A. Scandura, "Delegation and leader-member exchange: Main effects, moderators, and measurement issues,” Academy of Management Journal, vol. 41, no. 3, pp. 298-318, June, 1998. Article (CrossRef Link). 
[51] Richard M. Ryan and Edward L. Deci, "Self-determination theory and the facilitation of intrinsic motivation, social development, and well-being," American Psychologist, vol. 55, no. 1, pp. 6878, January, 2000. Article (CrossRef Link).

[52] Douglas E. Miller and Joseph T. Kunce, "Prediction and statistical overkill revisited," Measurement and Evaluation in Guidance, vol. 6, no. 3, pp. 157-163, July, 2018. Article (CrossRef Link).

[53] Ian C. K, Wong, George E. Mawer, Josemir W. A. S. Sander and Samden D. Lhatoo, "A pharmacoepidemiologic study of factors influencing the outcome of treatment with lamotrigine in chronic epilepsy,” Epilepsia, vol. 42, no. 10, pp. 1354-1358, December, 2001. Article (CrossRef Link).

[54] Ronald S. Halinski and Leonard S. Feldt, "The selection of variables in multiple regression analyses,” Journal of Educational Measurement, vol. 7, no. 3, pp. 151-158, September, 1970. Article (CrossRef Link).

[55] Park, W. W., Son, S. Y., Park, H. \& Park, H.S, “A proposal on determining appropriate sample size considering statistical conclusion validity,” Seoul Journal of Industrial Relations, 21, 51-85, 2010. Article (CrossRef Link).

[56] Jacques Defourny and Marthe Nyssens, "Conceptions of social enterprise and social entrepreneurship in Europe and the United States: Convergences and divergences," Journal of Social Entrepreneurship, vol. 1, no. 1, pp. 32-53, March, 2010. Article (CrossRef Link).

[57] Edwin M. Epstein, “The corporate social policy process: Beyond business ethics, corporate social responsibility, and corporate social responsiveness," California Management Review, vol. 29, no. 3, pp. 99-114, April, 1987. Article (CrossRef Link).

[58] Bruce Thompson, Exploratory and Confirmatory Factor Analysis: Understanding Concepts and Applications, American Psychological Association, Washington DC, 2004.

[59] Joel E. Cohen, Statistical Power Analysis for the Behavioral Sciences(2nd Edition), Lawrence Earlbaum Associates, New York, 1988.

[60] J. Reynaldo A. Santos, “Cronbach's alpha: A tool for assessing the reliability of scales,” Journal of Extension, vol. 37, no. 2, pp. 1-5, April, 1999. Article (CrossRef Link).

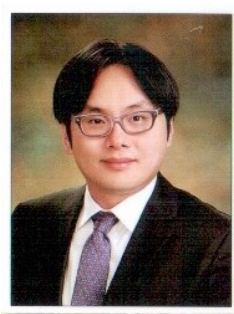

SangWoo Hahm is currently an assistant professor of College of Business Administration at Soongsil university, Seoul, Korea. He received his Ph.D, MS and BS in School of Business Administration from Soonsil University. His current research interests include ebusiness, management, The fourth industrial revolution, organizational behavior, interdisciplinary research and the like. 